\title{
CORRELATION BETWEEN BLOOD UREA AND CREATININE LEVEL IN PATIENTS WITH DIABETES MELITUS AT THE MINISTRY OF MARINE AND FISHERY CLINIC, INDONESIA
}

\author{
Derisca Yosa' ${ }^{1}$, Adik Wibowo²) \\ 1) Study Program in Health Service Management, \\ Faculty of Public Health, Universitas Indonesia \\ 2)Faculty of Public Health, Universitas Indonesia
}

\begin{abstract}
Background: The most frequent microvascular complications in patients with diabetes mellitus (DM) is diabetic nephropathy. Worldwide, diabetic nephropathy is the most common cause of endstage renal disease worldwide and a major cause of morbidity and mortality in DM patients. Urea and creatinine examinations are performed to find out kidney damage in patients with DM. This study aimed to report the correlation between blood urea and creatinine level in patients with DM at the Ministry of Marine and Fishery Clinic.

Subjects and Method: This was a cross-sectional study conducted at the Ministry of Maritime Affairs and Fisheries Clinic in August 2019. A total of 155 patients with DM with laboratory tests of urea and creatinine blood was selected for this study. The variables tested were blood urea and creatinine levels. The data of blood urea and creatinine levels were collected from medical records in a year period from January to December 2018. The data were analyzed using Spearman Rank correlation test.

Results: There was a positive correlation between urea and creatinine levels in the blood in DM patients $(\mathrm{r}=0.44 ; \mathrm{p}<0.001)$.

Conclusion: There is a positive and moderate association between blood urea and creatinine in DM patients.
\end{abstract}

Keywords: diabetes mellitus, urea, creatinine

\section{Correspondence:}

Derisca Yosa. Study Program in Health Service Management, Faculty of Public Health, Universitas Indonesia, Depok, West Java, Indonesia. Email: deriscayosa@gmail.com Mobile: o85775553559 .

\section{BACKGROUND}

The burden of diabetes mellitus continues to increase and the global prevalence is expected to increase from $6.4 \%$ in 2010 to $7.7 \%$ in 2030. Estimates showed that 285 million people worldwide have diabetes in 2010. This number represented $6 \%$ of the adult population aged between 20 and 79 years. It was expected that the prevalence will increase to almost $8 \%$ by 2030 by 438 million diagnosed patients (Shaw et al., 2010).

Deaths due to diabetes mellitus are highest in poor and developing countries by $\geq 80 \%$ (Jansson et al., 2015). According to data from the World Health Organization (WHO), the number of people with DM in Indonesia is the highest after India, China, and the United States. WHO predicts an increase in the number of people with DM in Indonesia from 8.4 million in 2000 to around 21.3 million in 2030. The International Diabetes Federation (IDF) in 2009. Predicted an increase in the number of people with DM from 7.0 million in 2009 to 12.0 million in 2030. Although there are differences in prevalence rates, both reports showed an increase in the number of people with DM as much as 2-3 times in 2030 (Ministry of Health, 2014). 
DKI Jakarta ranks first as a city with the highest prevalence of diabetes mellitus in Indonesia at 3.4 percent. The percentage of diabetes mellitus prevalence increased within five years from the 2013 Riskesdas data of 2.5 percent. While the highest prevalence of Diabetes Mellitus based on the level of work is $4.17 \%$ in civil servant/ military/ police/ BUMN/ BUMD types (Riskesdas, 2018).

Diabetes mellitus is a systemic disorder characterized by a chronic hyperglycemic state that is associated with inflammation and oxidative stress. This causes micro and macrovascular damage to many organs, especially kidneys, retina, and cardiovascular system (Folli et al., 2011). Diabetes mellitus (DM) is one of the leading causes of death in the world. $43 \%$ of deaths due to high blood glucose levels occur under the age of 70 years. The trend of diabetes mellitus in the world in 1980 to 2014 has increased significantly. The majority of diabetes mellitus in the world in 2014 which occurred at the age of more than 18 years is $8.50 \%$ (WHO, 2016).

Chronic complications of type 2 diabetes can be in the form of microvascular and macrovascular complications which can reduce the quality of life of patients. The main cause of death for people with type 2 diabetes is macrovascular complications. Macrovascular complications involve large blood vessels, namely coronary arteries, cerebral blood vessels, and peripheral blood vessels. Microvascular is a diabetes specific lesion that attacks the capillaries and retinal arterioles (diabetic retinopathy), renal glomerulus (diabetic nephropathy), and peripheral nerves (diabetic neuropathy) (Price and Wilson, 2006).

Chronic DM can cause changes in small blood vessels that can damage kidney consequently can cause severe kidney failure, and after 5-10 years to become a sig- nificant kidney damage problem (ADA, 2015; Koga et al., 2010). Good glycemic control can reduce the incidence of diabetic nephropathy. The earliest nephropathy disorder detected was microalbuminuria followed by a decrease in glomerular filtration rate (GFR) and an increase in serum creatinine concentration (Gonzalez, 2013).

The most frequent microvascular complication in people with DM is diabetic nephropathy in the kidney organs. The kidneys cannot resist hyperglycemia because the threshold for blood sugar is $180 \mathrm{mg} \%$ so that if hyperglycemia occurs, the kidneys cannot filter and absorb some glucose in the blood. One indicator of kidney function is to assess the glomerular filtration rate (GFR). GFR provides information about the amount of kidney tissue that is functioning, if the GFR value decreases, the levels of urea and creatinine will increase (Rendy, 2012; Toto, 2013).

Diabetes nephropathy which affects about one third of DM patients is the most common cause of end-stage kidney disease (ESRD) worldwide and is a leading cause of morbidity and mortality in patients with diabetes. This is due to the development of ESRD especially in patients with type 2 diabetes (Tuttle et al., 2014).

About 50\% of end-stage kidney failure in the United States is caused by diabetic nephropathy. Nearly $60 \%$ of people with hypertension and diabetes in Asia suffer from diabetic nephropathy (Satria, 2018). In 1981 diabetic nephropathy was the 6th leading cause of death in western countries and currently $25 \%$ of kidney failure patients undergoing dialysis are caused by diabetes mellitus especially DM type 2, for this type of DM is more common (Satria, 2018).

Biochemical markers play an important role in accurate diagnosis and in assessing risks and adopting therapies to im- 
prove clinical outcomes. Serum analysis of renal function markers such as urea, creatinine, uric acid, and electrolytes is used routinely (Gowda et al., 2010). Blood tests for Blood Urea Nitrogen (BUN) which is the main nitrogen end product of protein and amino acid catabolism, and creatinine which is a breakdown product of creatine phosphate in muscles, is excreted by the kidneys (Gowda et al., 2010; Kamal., 2014).

BUN is an indirect and crude measurement of kidney function that measures the amount of urea nitrogen in the blood and is directly related to the function of kidney excretion. The creatinine test diagnoses impaired kidney functions and measures the amount of creatinine phosphate in the blood (Kamal, 2014). Serum creatinine is the most routine marker used for assessment of renal function (Powers, 2008).

Urea and creatinine are good indicators of normal functioning kidneys and increased serum is an indication of kidney dysfunction (Kamal, 2014). BUN and serum creatinine are widely accepted and the most common parameters for assessing kidney function (Kamal, 2014; Suresh et al., 2014). In order to determine the existence of kidney damage in DM patients, it is necessary to do a blood examination consisting of urea and creatinine. In general, in private clinical laboratories and hospital laboratories have urea and creatinine examination parameters for kidney function test. Likewise, in the Laboratory of the Ministry of Maritime Affairs and Fisheries in Jakarta, parameters used for kidney function tests are urea and creatinine.

Data for 2018 showed that research had been conducted at the Clinic of the Ministry of Maritime Affairs and Fisheries. In this study, we intend to report the results of research on the description of urea and creatinine in people with DM at the Marine and Fisheries Ministry Clinic.

\section{SUBJECTS AND METHODS \\ 1. Study Design}

This study was conducted using an analytic observational research design with a cross sectional design. This research was conducted at the Ministry of Maritime Affairs and Fisheries Clinic in August 2019.

\section{Population and Sample}

The population is all type $2 \mathrm{DM}$ patients who visit the Clinic of the Ministry of Maritime Affairs and Fisheries, while the sample is all visits of type $2 \mathrm{DM}$ patients who also conduct laboratory tests with urea and creatinine blood tests. The sample size taken in this study was 155 respondents. Sampling was carried out using secondary data in the form of patient medical records. Data was taken in a period of 1 year from January 2018 to December 2018 at the Clinic of the Ministry of Maritime Affairs and Fisheries and carried out non-probability sampling using consecutive sampling techniques.

\section{Data Analysis}

The variables tested were blood urea and creatinine levels in diabetics using the Spearman Rank correlation test.

\section{RESULTS}

Research on the relationship of serum urea levels with serum creatinine levels in patients with type 2 diabetes mellitus at the Marine and Fisheries Ministry Clinic was conducted during August 2019. The sample used for this study amounted to 155 patients. Data were analyzed by univariate and bivariate using Rank Spearman correlation test to determine the relationship of serum urea levels with serum creatinine levels. Patient characteristics are illustrated in Table 1. 
Table 1. The characteristics of patients

\begin{tabular}{lcc}
\hline Characteristics & Frequency & Percent \\
\hline Age (year) & & \\
$25-34$ & 5 & 3.2 \\
$35-44$ & 28 & 18.1 \\
$45-54$ & 59 & 38.1 \\
$55-64$ & 60 & 38.7 \\
$65-74$ & 3 & 1.9 \\
Total & 155 & 100 \\
Age & & \\
Male & 102 & 65.8 \\
Female & 53 & 34.2 \\
Total & 155 & 100 \\
Educational & & \\
Background & & \\
SHS & 18 & 11.6 \\
D3 & 2 & 1.3 \\
Bachelor & 80 & 51.6 \\
Master & 42 & 27.1 \\
Doctor & 13 & 8.4 \\
Total & 155 & 100 \\
\hline
\end{tabular}

Based on table 1, it was found that the age of most patients was in the range of $55-64$ years, namely 60 people (38.7\%) while in the range of 25-34 years, $35-44$ years, 45-54 years, and 65-74 years respectively 5 people $(3.2 \%), 28$ people (18.1\%), 59 people (38.1\%), and 3 people (1.9\%).

The gender distribution of patients is more in the male gender 102 people (65.8\%) while the female gender is 53 people (34.2\%). As for the distribution of patient education levels, most patients with undergraduate education were 80 people (11.6\%) while for master education, SHS, doctoral degree, and D3 respectively 42 people (27.1\%), 18 people (11.6\%), 13 people (8.4\%), and 2 people (1.3\%).

In the chemical examination, urea and creatinine was analyzed by univariate and bivariate, which are described in Table 2. Based on table 2, it can be seen that the distribution of patients on the urea variable, is most prevalent in the group of normal urea patients, namely 127 people (81.9\%) while for the low urea category of
21 people (13.5\%), and the high urea category of 7 people $(4.5 \%)$.

Table 2. The distribution of urea and creatinine levels in patients with diabetes mellitus at the Marine and Fisheries Ministry Clinic.

\begin{tabular}{lcc}
\hline \multicolumn{1}{c}{ Variable } & Frequency & Percentage \\
\hline Urea & & \\
Low & 21 & 13.5 \\
Normal & 127 & 81.9 \\
High & 7 & 4.5 \\
Total & 155 & 100.0 \\
Creatinine & & \\
Low & 3 & 1.9 \\
Normal & 134 & 86.5 \\
High & 18 & 11.6 \\
Total & 155 & 100.0 \\
\hline \multicolumn{2}{c}{ As for the distribution of patients in }
\end{tabular}

the creatinine variable, most were in the normal creatinine group, which was 134 people (86.5\%) while for the low creatinine category were 3 people (1.9\%), and the high creatinine category were 18 people (11.6\%).

Bivariate analysis between urea and creatinine variables was done using the Spearman Rank correlation test. The Alternative Hypothesis ( $\mathrm{Ha}$ ) states that there is a relationship between urea levels and creatinine levels.

The Spearman Rank correlation test results showed a positive correlation between urea levels and creatinine levels in the blood ( $\mathrm{r}=0.44 ; \mathrm{p}<0.001)$. This shows that the level of urea with creatinine levels has a moderate positive pattern, which means the more urea level in the blood, the higher the creatinine level $(r=0.44)$. Statistical test results showed that there was a relationship between urea levels and creatinine levels ( $\mathrm{p}<0.001)$.

\section{DISCUSSION}

The age distribution in our results was mostly in the 55-64 years age group, and there was a tendency for the prevalence of 
diabetes to increase with age. This is in line with Riskesdas data on the prevalence of Diabetes Mellitus based on doctor's diagnosis in 2013 and 2018. The age group that suffers the most from Diabetes was in the 55-64 years age group. As for what is similar to the results of our study, Rahmawati et al. (2018) which stated that the majority of the diabetic group was at the age of 50-59 years.

People aged 40 years and over were vulnerable to obesity because they were less active in their daily physical activities. The decrease of exercise was also one of the factors that influence the onset of DM. Physical activity in question is any gesture that can eliminate calories, such as going up and down stairs, sweeping, gardening, exercising, and ironing. Age can affect the risk and the occurrence of type 2 diabetes. Increases in blood sugar levels are closely related to age, so the prevalence of type 2 diabetes will increase along with increasing age and result in higher impairment of glucose tolerance (Lathifah, 2017).

According to Smeltzer and Bare (2014), age is closely related to an increase amount of blood sugar. The more you age, the higher the risk of developing type 2 diabetes. The aging process can result in changes in the body's anatomical, physiological, and biochemical systems in which one of its effects is an increase in insulin resistance.

In addition, according to Leroith (2012), the incidence of type $2 \mathrm{DM}$ in the old age groups occurs not only due to environmental factors but also from physiological factors. This is supported by research conducted by Wilmot and Idris (2014) which showed that the attack from type $2 \mathrm{DM}$ in adults is because the individual is obese, has a history of DM type 2 offspring, has an unhealthy lifestyle, and black race.
According to Tjokroprawiro (2004), the age limit of 50-60 years is the age limit that often experiences sudden attacks of blood vessel disease both in the brain and heart, but the significant relationship between the two is still uncorrectable.

Based on the above theory, it can be seen that with increasing age the Ministry of Maritime Affairs and Fisheries employees can risk increasing the incidence of diabetes because in the aging process resulting in changes in the anatomical system and metabolic function of the body decreases. In addition, the occurrence of diabetes in employees is also influenced by obesity, lack of activity, unhealthy lifestyles, and environmental factors.

The results of the analysis test showed that the relationship between sex with DM patients was more common in men. These results are similar to the study conducted by Yanto et al. (2017), showed that the number of people with type 2 diabetes mellitus is more male than female. But, the difference in the number is not too significant and cannot adequately describe gender as a factor in the incidence of diabetes mellitus. However, this should also be watched out because according to several other studies explained that male sex has a risk of diabetes increasing faster.

Scientists from the University of Glasgow, Scotland revealed that after observing 51,920 men and 43,137 women. All of them are people with type 2 diabetes and generally have a body mass index (BMI) above the overweight limit. Men with diabetes with an BMI averaged 31.83 $\mathrm{kg} / \mathrm{m} 2$ while women had only experienced it with a BMI of $33.69 \mathrm{~kg} / \mathrm{m}^{2}$. This difference in risk is influenced by the distribution of body fat. In men, fat accumulation is concentrated around the abdomen, triggering central obesity which 
is more at risk of triggering metabolic disorders (Yanto et al., 2017).

While from research conducted by Leslie et al. (2013), it can be seen that the actual incidence of type $2 \mathrm{DM}$ is more susceptible to occur in men compared to women but in reality female are more affected by type $2 \mathrm{DM}$ compared with men. This is because women in the community have higher life expectancy than men so that more elderly women cause the increase in number of women with type 2 diabetes (Leslie et al., 2013).

The results showed that the highest number of patients of diabetes mellitus is bachelor graduates and the second highest number is master program. This study is also supported by data from Riskesdas in 2013 and 2018 that the prevalence of diabetes mellitus tends to be higher in people who have a high level of education (D1/ D2/ D3/ PT). This is different from the statement of Notoatmodjo (2011) in his book that increasing the level of education will increase awareness for healthy living and pay attention to lifestyle, and eating patterns. Individuals with low education have the risk of not paying attention to lifestyle and eating patterns, and what to do in preventing DM (Notoatmodjo, 2011). Education is a long-term behavioral investment. Increased knowledge alone does not affect health indicators, but instead a person is required to perform a health behavior so that health indicators can be realized through the level of education that has been achieved (Notoatmodjo, 2007).

Research Palimbunga et al. (2017) showed that there was no relationship between the level of education with the incidence of Type $2 \mathrm{DM}$ in outpatients in the Internal Medicine Polyclinic at GMU Pancaran Kasih Hospital Manado. This is because patients with low or high levels of education also have other risk factors that affect patients with DM. Education level is not the only factor that can influence the incidence of DM (Palimbunga et al., 2017). The results of this study are supported by another study conducted by Allorerung (2016) which stated that there is no relationship between the level of education with the incidence of Type 2 diabetes (Palimbunga et al., 2017).

Ministry of Maritime Affairs and Fisheries employees tend to have unhealthy eating patterns and lack of physical activity in the ministry office environment. Many employees are so busy with work that they don't pay attention to healthy lifestyles and are easily influenced by the environment. Thus, diabetes mellitus is not associated with higher education. This is because there are other factors involved that influence the incidence of diabetes mellitus.

Univariate analysis results showed that there were $4.5 \%$ of patients whose urea levels increased and $11.6 \%$ of patients whose creatinine levels also increased from the reference value. In addition, there are patients with normal urea levels of $81.9 \%$ and normal creatinine levels of $86.5 \%$ (urea: $17-43 \mathrm{mg} / \mathrm{dl}$, creatinine: $0.6-1.3$ $\mathrm{mg} / \mathrm{dl}$ ) (Ministry of Health, 2011).

Based on these results, it can be concluded that the largest group of patients has urea and creatinine levels that are still in the normal range. This means that the patient has not shown signs of complications of diabetes mellitus especially diabetic nephropathy.

According to Tjokroprawiro (2004), diabetes mellitus to be able to cause complications requires several other factors that also play an important role in causing uncontrolled blood glucose, so that it has a negative impact on other organs of the body. In addition, a study conducted by Bamanikar et al. (2016) showed that uncontrolled blood sugar levels would cause 
an increase in serum urea levels and thereby increasing the chances of patients suffering from diabetic nephropathy.

Based on the research and theory above, it can be concluded that most patients tend to carry out routine controls to maintain the stability of blood sugar levels in the body so as to prevent complications.

Bivariate results show that the urea and creatinine levels have a moderate positive relationship, which means that in general urea and creatinine are absorbed through the kidneys together. If the kidneys are disturbed, then the urea and creatinine will both experience an increase in serum levels in the blood. However, if the kidney is disturbed, then the increase is not too fast or moderate because it depends on other factors that also play an important role in causing these complications.

Urea is a waste product of protein metabolism that is normally transferred from the blood to the kidneys. The amount of urea in the blood is determined by dietary protein and the ability of the kidneys to excrete urea. If the kidneys are damaged, urea will accumulate in the blood. Increased plasma urea indicates kidney failure in performing its filtration function (Lamb et al., 2006).

Creatinine is a product of muscle protein which is the end result of muscle metabolism that is released from muscles at almost constant speed and is excreted in the urine at the same speed. Creatinine is excreted by the kidneys through a combination of filtration and secretion, the concentration is relatively constant in plasma from day to day, levels above the normal value indicate the existence of impaired kidney function (Alfarisi et al., 2013).

Urea and creatinine in the blood are good indicators for assessing kidney function. If there is an increase in urea and creatinine levels in the blood, then this can be an indication of damage to kidney function. More than $80 \%$ of DM patients in the Marine and Fisheries Ministry's Clinic have normal levels of urea and creatinine. This is because these patients tend to have good glycemic control to prevent the incidence of diabetic nephropathy.

Monitoring and evaluation of urea and creatinine examination in the blood need to be done further to prevent nephropathic complications for patients who have above normal urea and creatinine results. Monitoring and evaluation in controlling blood glucose levels also need to be done in DM patients to prevent other chronic complications.

\section{REFERENCES}

Alfarisi S, Basuki W, Susantiningsih T (2013). Perbedaan kadar kreatinin serum pasien diabetes melitus tipe-2 yang terkontrol dengan yang tidak terkontrol di RSUD dr. H. Abdul Moeloek bandar lampung tahun 2012 (The differences in serum creatinine levels in patients with type-2 diabetes mellitus controlled and not controlled in RSUD dr. H. Abdul Moeloek city of Lampung in 2012). Majority, 2 (5): 129-36.

American Diabetes Association (2015). Diagnosis and classification of diabetes melitus. Diabetes Care; 35: S64-S71.

Rahmawati A, Hargono A (2018). Faktor dominan neuropati diabetik pada pasien diabetes melitus tipe 2 (Dominant factors of diabetic neuropathy in patients with type 2 diabetes mellitus). Surabaya: Jurnal Berkala Epidemiologi, 6 (1): 60-68.

Wilmot E, Idris I (2014). early onset type 2 diabetes: risk factor, clinical impact, and management. J Ther Ad in Chronic Dis. 5 (6): 234-244. 
Folli F, Corradi D, Fanti P, Davalli A, Paez A, Giaccari A, Perego C, Muscogiuri G (2011). The role of oxidative stress in the pathogenesis of type 2 diabetes mellitus micro- and macrovascular complications: avenues for a mechanistic based therapeutic approach. Curr Diabetes Rev 2011. 7 (5): 313324 .

Gonzalez Suarez ML, Thomas DB, Barisoni L, Fornoni A (2013). Diabetic nephropathy: Is it time yet for routine kidney biopsy? World J Diabetes, 4 (6): 24555.

Gowda S, Desai PB, Kulkarni SS, Hull VV, Math AAK, Vernekar SN (2010). Markers of renal function tests. N Am J Med Sci. 2 (4): 170-73.

Satria H, Decroli E, Afriwardi (2018). Faktor risiko pasien nefropati diabetik yang dirawat di bagian penyakit dalam RSUP Dr. M. Djamil Padang (Risk factors for diabetic nephropathy patients cared for in internal medicine M. Djamil Padang Hospital). Padang: Jurnal Kesehatan Andalas.

Jansson S, Fall K, Brus O, Magnuson, A., Ostgren C, Rolandsson O (2015). Prevalence and incidence of diabetes mellitus: $S$ nationwide populationbased pharmaco-epidemiological study in Sweden. Diabetic Medicine, 32 (10): 1319-1328.

Kamal A (2014). Estimation of blood urea (BUN) and serum creatinine level in patients of renal disorder. IJFALS. 4 (4): 199-202.

Ministry of Health RI (2011). Pedoman interpretasi data klinik (guidelines for interpretation of clinical data). Jakarta: Ditjen Kefarmasian Ministry of Health RI .

Ministry of Health RI (2013). Riset kesehatan dasar (basic health research). Jakarta: Badan Penelitian dan Peng- embangan Kesehatan Kementerian RI.

Ministry of Health RI (2014). Situasi dan analisis diabetes (diabetes situation and analysis). Jakarta: Infodatin Ministry of Health RI .

Ministry of Health RI (2018). Riset kesehatan dasar (basic health research). Jakarta: Badan Penelitian dan Pengembangan Kesehatan Kementerian RI.

Koga M, Kasayama S (2010). Clinical impact of glycated albumin as another glycemic kontrol maker. Endocr J. 57 (9): 751-62.

Lathifah NL (2017). Hubungan durasi penyakit dan kadar gula darah dengan keluhan subyektif penderita diabetes melitus (The relationship between disease duration and blood sugar levels with subjective complaints of patients with diabetes mellitus). Surabaya: Jurnal Berkala Epidemiologi, 5 (2): 231-239.

Ashwood ER, Bruns DE, Burtis A (2006). Kidney function test. Tietz Textbook of Clinical Chemistry and molecular diagnostic. $4^{\text {th }}$ Edition. Elsevier Saunders, St Louis.

Leroith D (2012). Prevention of type 2 diabetes. New York: Springer.

Leslie D, Lansang C, Coppack S, Kennedy L (2013). Diabetes: Clinician's Desk Reference. New York: CRC Press.

Rendy MC, Margareth TH (2012). Asuhan keperawatan medikal badah penyakit dalam (Medical nursing in internal medicine surgery). Yogyakarta: Nuha Medika.

Notoatmodjo S (2007). Kesehatan masyarakat ilmu dan seni (public health sciences and arts). Jakarta: Rineka Cipta. 
Notoatmodjo S (2011). Ilmu perilaku kesehatan (Health behavioral sciences). Jakarta: Rineka Cipta.

Powers AC (2008). Diabetes Mellitus. In: Fauci AS, Braunwald E, Kasper DL, Hauser SL, [3] Longo DL, Jameson JL et al, editors. Harrison's principles of internal medicine. $17^{\text {th }}$ ed. United States of America (NY): Mc-Graw Hill Companies. United States of America: MC-Graw Hill.

Palimbunga TM, Ratag BT, Kaunang WPJ. (2017). Faktor-faktor yang berhubungan dengan kejadian diabetes melitus tipe 2 di RSU Gmim Pancaran Kasih Manado (Factors related to the type 2 diabetes mellitus incidence in RSU Gmim Pancaran Kasih Manado). Manado: Fakultas Kesehatan Masyarakat Universitas Sam Ratulangi Manado

Price SA, Wilson LM (2006). Patofisiologi konsep klinis proses-proses penyakit (Pathophysiology of clinical concepts of disease processes). Edisi ke-6. Jakarta: EGC.

Bamanikar SA, Bamanikar AA, Arora A (2016). Study of Serum urea and Creatinine in Diabetic and nondiabetic patients in in a tertiary teaching hospital. J. Clin Med Res, 2 (1): 12-15.

Shaw JE, Sicree RA, Zimmet PZ (2010). Global estimates of the prevalence of diabetes for 2010 and 2030. Diabetes Res Clin Pract. 87 (1): 4-14.

Smeltzer SC, Bare (2014). Keperawatan medikal bedah Brunner dan Suddarth. Edisi ke-12. Jakarta: EGC.

Suresh G, Ravi Kiran A, Samata Y, Naik P, Kumar V (2014). Analysis of blood and salivary urea levels in patients undergoing haemodialysis and kidney transplant. J Clin Diagn Res. 8 (7): ZC18-20.

Syahlani A (2016). Hubungan diabetes melitus dengan kadar ureum kreatinin di poliklinik geriatri RSUD Ulin Banjarmasin (The relationship between diabetes mellitus and creatinine ureum levels in geriatric polyclinic Ulin Regional Hospital Banjarmasin). Kalimantan Selatan.

Tjokroprawiro A (2004). DM: klasifikasi, diagnosis, dan terapi (DM: classification, diagnosis, and therapy). Jakarta: PT. Gramedia Pustaka Utama.

Suharyanto T, Majid A (2013). Asuhan keperawatan pada klien dengan gangguan sistem perkemihan (Nursing care for clients with urinary system disorders). Jakarta: CV.Trans Info Media.

Tuttle KR, Bakris GL, Bilous RW, Chiang JL, de Boer IH, Goldstein-Fuchs J, Hirsch IB, et al. (2014). Diabetic kidney disease: a report from an ADA Consensus Conference. Am J Kidney Dis. 64 (4): 510-533.

World Health Organization (2018). Global Report on Diabetes.

Yanto A, Setyawati D (2017). Dukungan keluarga pada pasien diabetes mellitus tipe 2 di Kota Semarang (Family support for type 2 diabetes mellitus patients in Semarang City). Semarang: Prosiding Seminar Nasional Publikasi Hasil-Hasil Penelitian dan Pengabdian Masyarakat. 